\title{
Human Capital Plan for Business Startups "Jamu Partnership" in Indonesia
}

\author{
Andhika Saputra ${ }^{1}$, Rhian Indradewa', Tantri Yanuar Rahmat Syah ${ }^{3}$, \\ Diana Fajarwati ${ }^{4}$
}

1,2,3,4 Department Management, Faculty Economic and Business, Esa Unggul University, Jakarta - Indonesia

Corresponding Author: Andhika Saputra

\begin{abstract}
Background - PT OAM is a jamu partnership business startup company in Indonesia. This company is here to answer the customer pain and gain. In an effort to be competitive and sustainable in the jamu partnership business, this company uses its competitive advantages in the form of an easy partnership process, good product taste and product innovation and sustainable partnerships. Of course, this competitive advantage can only be maintained and developed if the company has competent human resources. In actual process operations, PT OAM requires good human resources planning. This is because human resources in a company are important and must be managed optimally.
\end{abstract}

Method - Using Human Capital Plan, and Organizational Culture.

Result - This analysis help to preparing and implementing each of its human capital activities in PT OAM. With good human capital plan the business can be competitive and sustainable.

Keywords: Human Capital Plan, Human Resources, Startups, Jamu Partnership.

\section{INTRODUCTION}

PT OAM is a jamu partnership business startup company in Indonesia. This company is here to answer the customer pain and gain in the form of the stigma of bitter jamu products, the difficulty of starting a business for the middle and lower economic community, the difficulty of using your own brand in business and the need for assistance in running a business, especially
SMEs. Jamu is a traditional health drink in Indonesia which is currently much favored by the public. This happens because the awareness of healthy living in the community increases by $19 \%$ every year based on a survey of insurance institutions in Indonesia. Another positive thing is the existence of government regulations that support the jamu partnership business.

In an effort to be competitive and sustainable in the jamu partnership business, this company uses its competitive advantages in the form of an easy partnership process, good product taste and product innovation and sustainable partnerships. Of course, this competitive advantage can only be maintained and developed if the company has expert human resources (Eriyanto et al., 2021). As a newly established startup company, PT OAM requires good human resources planning. This is because human resources in a company are important and must be managed optimally. If the company does not plan properly, it will be difficult for the company to develop and compete with its competitors. Therefore human resources planning is a very important element of PT OAM to maintain the competitive advantage it currently has. Human resources owned by the company must also be control and managed properly, because human resources have the knowledge, skills, and abilities needed by the organization (Armstong \& Taylor, 2010). 


\section{MATERIALS AND METHODS}

PT OAM human capital planning is prepared according to the framework in Figure 2.1 below.

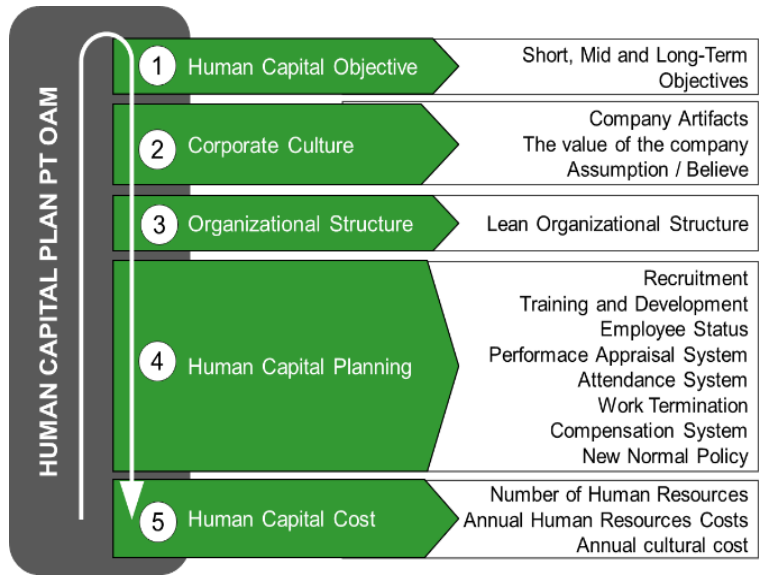

Figure 2.1 PT OAM Human Capital Framework Source: Author, 2021.

\subsection{Human Capital Objective}

PT OAM determines the objectives of human resources planning in accordance with the company's vision, mission and strategy objectives. This is because human resource planning is very influential in the overall organizational planning process (Mohammed et al., 2013).

\subsection{Corporate Culture}

According to Schein (2004), culture is related to certain values that managers try to instill in their organizations. Corporate culture in general can accommodate some diversity and can provide employee comfort and job satisfaction (Niam \& Syah, 2019). Seeing the importance of corporate culture, PT OAM will encourage and implement the implementation of corporate culture, values and assumptions on each employee, so that employees are able to produce optimal performance to achieve the company's vision, mission, and strategic goals.

Culture consists of artifacts, values and beliefs also assumptions (Schein, 2004). Artifacts are visible organizational structures and processes. Values and beliefs related to strategies, goals, philosophies. While assumptions are beliefs, perceptions, thoughts, and feelings that are not realized, taken for granted (Schein, 2004). PT OAM will apply this in establishing a strong organizational culture.

\subsection{Organizational Structure}

Organizational structure in PT OAM will be managed in accordance with the predetermined human capital objectives, namely the lean organization approach. In addition to a lean number of human resources, and performance evaluation, effective reward system and management style that encourages innovative activities in lean organizations are also suggested (Peek, B., \& Chen, 2011). This is intended so that PT OAM human resources are always innovative both for the development of the company and their personal abilities. As a startup company, PT OAM organizational structure will always be dynamic in accordance with certain environments, including types and environmental variables (Bruns, T., \& Stalker, 1961). The organizational structure of PT OAM itself describes the roles and responsibilities of each individual, how the coordination includes direct supervision, standardization of work processes, achievement of targets, required skills and processes of mutual adjustment (Mintzberg, 1980). Companies also need to align tasks and conditions to suit their environment (Drucker, 2006). Evaluation of PT OAM organizational structure will be carried out based on the results of employee performance assessments, because each organization has strengths and weaknesses in its business functional areas (David, 2011).

\subsection{Human Capital Plan}

PT OAM human capital planning includes recruitment, training and development, employee status, performance appraisal, attendance, work termination, compensation system and new normal policy. The employee recruitment system refers to hard skill competencies according to company needs, as well as soft skills based on qualities that are more intangible in a person (Townsend, 2007). Training and development programs are provided by PT 
OAM for both company employees and employees who work in partners. Through this the company's management offers benefits, binds and motivates its employees (Pernkopf, \& Brandl, 2011). In general, PT OAM human capital planning is to develop HR planning and training to develop a better company (Putra et al., 2019). The employee compensation system will be given proportionally according to the results of the annual performance appraisal by taking into account the company's financial condition. Basically, with high compensation, the level of job satisfaction and employee performance will also be higher (Sidabutar et al., 2020). The company will also implement a new normal policy to ensure that the company's human resources are well maintained. Implementation will refer to the social distancing protocol or the new normal protocol in accordance with Indonesian government regulation (Nugraha, 2020).

\subsection{Human Capital Cost}

PT OAM human capital cost planning includes salaries, benefits, insurance, corporate culture, training and development, etc. Training and development costs will also be the focus of PT OAM because it is a startup company, because training and development can improve organizational performance and productivity (Acemoglu, D., \& Pischke, 1999).

\section{DISCUSSION}

This discussion section will explain the application of human capital at PT OAM as a startup company.

\subsection{Human Capital Objective}

Human capital objectives for PT OAM are divided into several stages including short, mid and long-term, that we can see in Table 3.1 below.

Table 3.1 PT OAM Human Capital Objective

\begin{tabular}{|l|ll|}
\hline \multicolumn{1}{|c|}{ Category } & & \multicolumn{1}{c|}{ Objective Contents } \\
\hline Short-term & 1. & Fulfill 100\% of human resource needs in the first year. \\
(Y.0 to <Y.1) & 2. & $100 \%$ of the human resources has the ability according to the company's needs.. \\
\hline Mid-term & 1. & Conduct employee training and development. \\
(Y.1 to Y.2) & 2. & Encourage 100\% corporate culture implementatio. \\
& 3. & Evaluating employee performance with rewards and punishments every once year. \\
\hline Long-term & 1. & Implementation of continuous improvement competition twice per year. \\
$(Y>2)$ & 2. & Human resources contributes to the company's business development. \\
\hline
\end{tabular}
Source: Author, 2021.

\subsection{Corporate Culture}

Figure 3.1 below shows the implementation of PT OAM corporate culture. Each element of culture is applied in different times on a daily, monthly, quarterly and yearly basis.

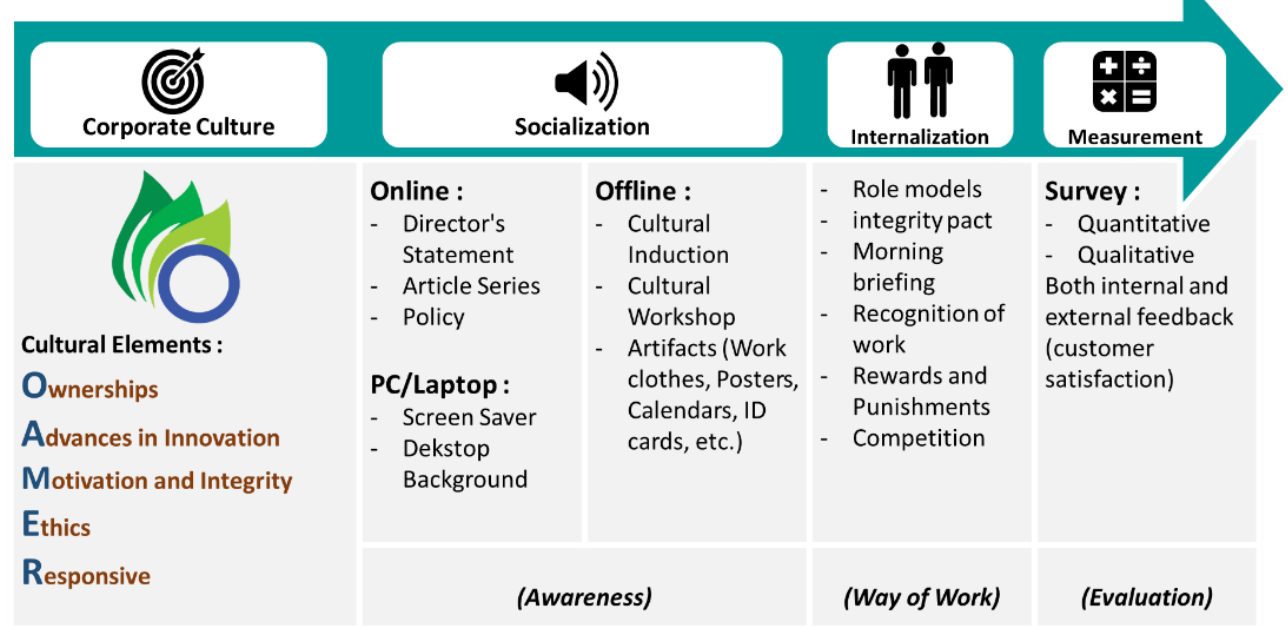

Figure 3.1 PT OAM Culture Implementation Framework Source: Author, 2021. 
Some of the things that are included in the corporate culture are as follows:

a. Artifact, the company uses artifacts containing company culture in the form of work clothes, posters, calendars and ID cards, and others. Using a company logo and room layout design that has a modern, traditional nuance.

b. Work uniform, The company uses a uniform design with a white base color with a company logo on the front and back. The use of this uniform is intended to increase discipline, a sense of ownership of the company and show the level of credibility of the company's employees.

c. Logo, the company uses a leaf logo with a combination of light green, green and blue as shown in Figure 3.1 symbolizing back to nature.

d. Office design, with a modern traditional nuance by using tables, chairs and other equipment with jamu products.

As for the values, assumptions / beliefs can be seen in the Table 3.2 below.

Table 3.2 PT OAM Values, Assumptions / Beliefs

\begin{tabular}{|l|l|}
\hline Values & \multicolumn{1}{c|}{ Assumptions / Beliefs } \\
\hline Ownerships & $\begin{array}{l}\text { Employees believe in the company's vision and mission, so they understand the consequences and their role in } \\
\text { the company. }\end{array}$ \\
\hline $\begin{array}{l}\text { Advances in } \\
\text { innovation }\end{array}$ & $\begin{array}{l}\text { Employees believe in the results of annual performance evaluations, rewards for creative ideas and continuous } \\
\text { improvement activities that are useful for the progress of the company. }\end{array}$ \\
\hline $\begin{array}{l}\text { Motivation and } \\
\text { Integrity }\end{array}$ & $\begin{array}{l}\text { Employees believe in punishment if they do not have high motivation and integrity and reward for the } \\
\text { opposite. }\end{array}$ \\
\hline Ethics & $\begin{array}{l}\text { Believing in the importance of open communication, mutual respect, respect and ethics in business is the basis } \\
\text { for making decisions. }\end{array}$ \\
\hline Responsive & $\begin{array}{l}\text { Ensuring that annual evaluations are carried out regularly for the level of employee responsiveness to internal } \\
\text { and external issues of the company. }\end{array}$ \\
\hline
\end{tabular}

Source: Author, 2021.

\subsection{Organizational Structure}

Figure 3.2 below shows the planning of PT OAM organizational structure using a lean organization approach, it can work because the production process is carried out by partner companies.

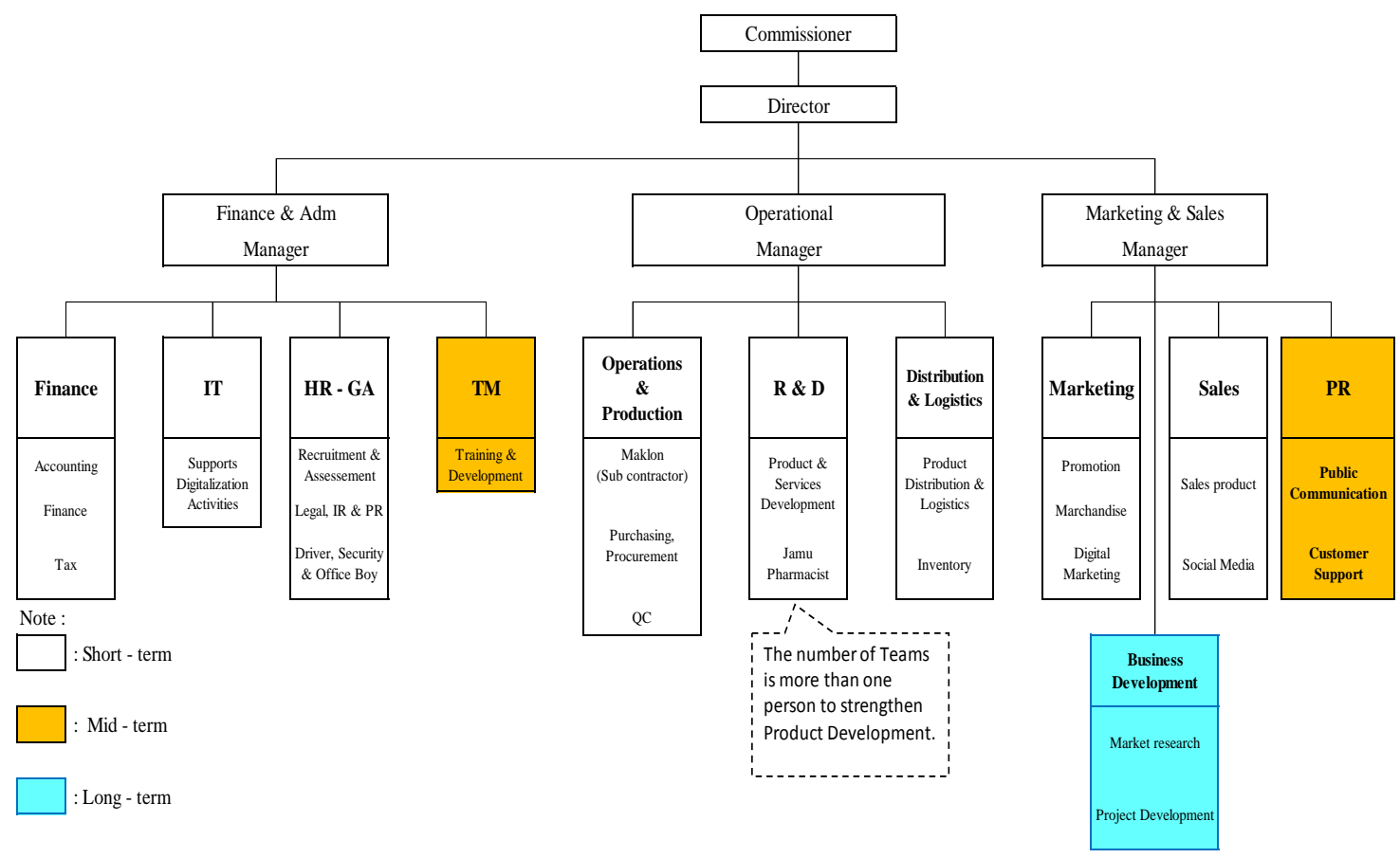

Figure 3.2 PT OAM Organizational Structure.

Source: Author, 2021. 


\subsection{Human Capital Plan}

PT OAM human capital planning activities include recruitment, training and development, employee status, performance appraisal, attendance, work termination, compensation system and new normal policy. Where is the explanation as follows:

a. Recruitment, in terms of employee recruitment activities, PT OAM uses two recruitment approaches, namely external and internal. Internal recruitment itself is divided into three types of needs, namely job rotation, promotion and employee demotion. The stages of recruitment can be seen in the following Table 3.3.

Table 3.3 PT OAM Recruitment Stages.

\begin{tabular}{|c|l|}
\hline Stage & \multicolumn{1}{|c|}{ Activity } \\
\hline $1^{\text {st }}$ & Employee needs analysis. \\
\hline $2^{\text {nd }}$ & Board of Directors approval. \\
\hline $3^{\text {rd }}$ & Employee recruitment. \\
\hline $4^{\text {th }}$ & Employee placement. \\
\hline
\end{tabular}

b. Employee Training and Development, Employee training is intended to increase the employee's mastery of skills for a particular job and what he is currently doing. Meanwhile, employee development is intended so that employees master new skills and are able to take on greater responsibilities so that career planning can run well. The stages of training and development can be seen in the following Table 3.4 .

Table 3.4 PT OAM Training and Development Stages.

\begin{tabular}{|c|l|}
\hline Stage & Activity \\
\hline $1^{\text {st }}$ & Analysis of training and development needs. \\
\hline $2^{\text {nd }}$ & Training and development goals. \\
\hline $3^{\text {rd }}$ & Implementation of training and development. \\
\hline $4^{\text {th }}$ & Evaluation of training and development results. \\
\hline
\end{tabular}

Figure 3.3 below shows the training for employees and partners of PT OAM.

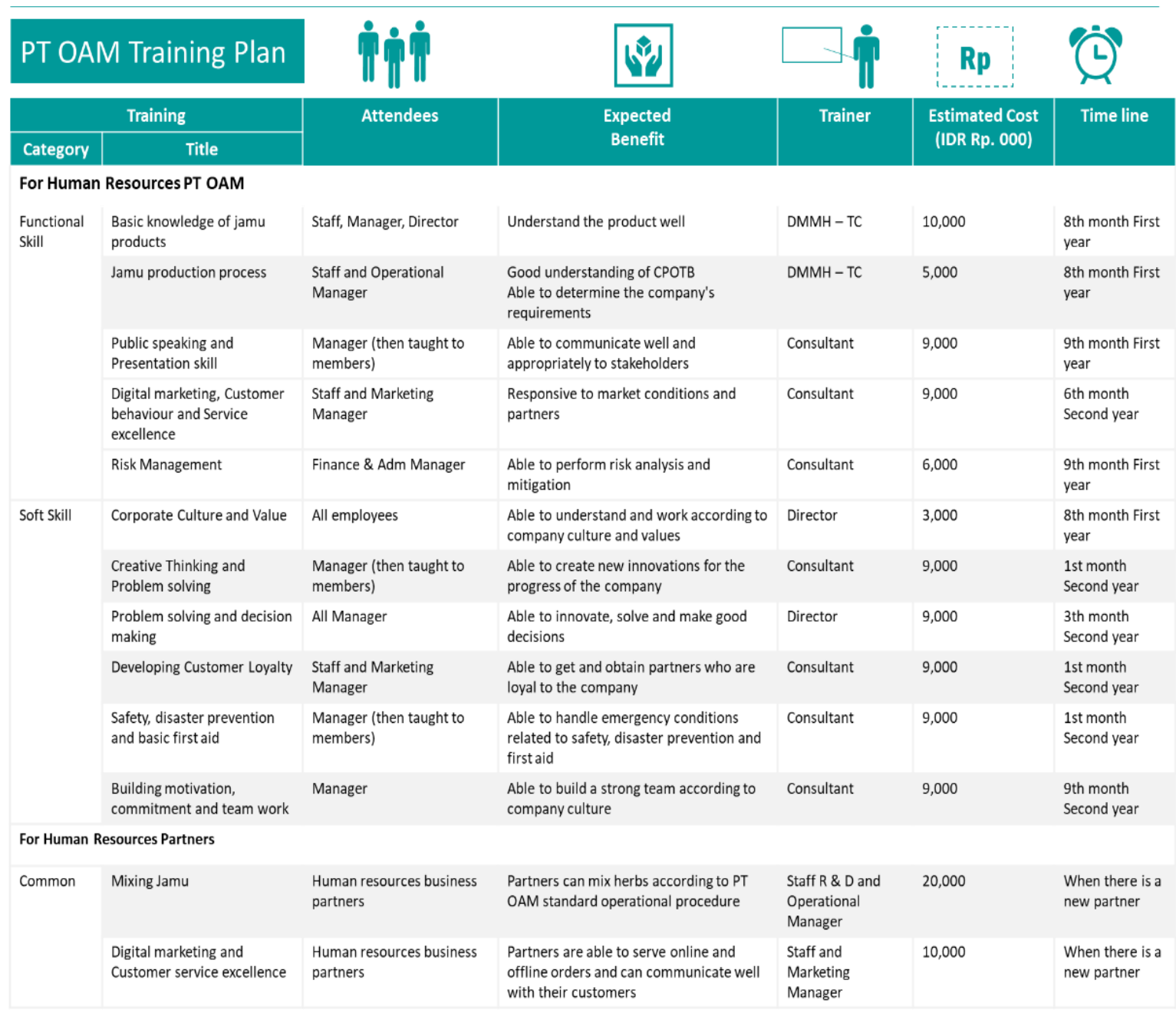

Figure 3.3 PT OAM Training for Employees and Partners. Source: Author, 2021. 
c. Employee Status, in this case PT OAM is guided by Government Law No. 11 of 2020 concerning Job Creation Article 56 paragraph (1) which states that work agreements are made for a certain time or for an indefinite time. So that the company will use three types of employee status, namely permanent (PKWT/Specific Time Work Agreement), contract (PKWTT/Indefinite Time Work Agreement).

d. Employee Performance Appraisal can be seen in table 3.5 below.

Table 3.5 PT OAM Performace Appraisal Stages.

\begin{tabular}{|c|c|}
\hline Stage & Activity \\
\hline $1^{\mathrm{st}}$ & Each employee determines his KPI target. \\
\hline $2^{\text {nd }}$ & $\begin{array}{l}\text { Target supervisor checked } \\
\text { approved/revised by superior. }\end{array}$ \\
\hline $3^{\text {rd }}$ & $\begin{array}{l}\text { If it has been approved, the employee works } \\
\text { according to the target. }\end{array}$ \\
\hline $4^{\text {th }}$ & $\begin{array}{l}\text { First assessment in the middle of the year, for } \\
\text { correction and direction. }\end{array}$ \\
\hline $5^{\text {th }}$ & $\begin{array}{l}\text { Second assessment at the end of the year, to } \\
\text { see total performance. }\end{array}$ \\
\hline
\end{tabular}

e. Employee Attendance System, PT OAM uses two employee attendance control systems, firstly using a finger print machine for employees who work statically (working on the spot), secondly using work results reports (email) and location sharing for employees who work dynamically (eg marketing department). Both attendance systems will be validated on a daily basis by the related manager. f. Work Termination System, in this case PT OAM is guided by Government Law No. 11 of 2020. The types include termination of employment during the probationary period, employee resigns, company closes, due to serious violations, and employee pension.

g. Compensation System, PT OAM in providing compensation to employees will consider two main things, such as the structural responsibility burden and the results of the employee performance assessment carried out per semester. In addition, other factors such as employee education and experience, economic conditions, government regulations, level of compensation for similar companies and company capabilities will also be considered. Two types of compensation are used, namely direct and indirect compensation.

New Normal Policy, PT OAM will be follow based on the latest government regulations such as keeping a distance, wearing a mask, etc.

\subsection{Human Capital Cost}

As a startup company, PT OAM will be formed as lean as possible (lean organization) so that it is hoped that the budget related to human resources will not be too large. The total human resources and human capital costs in the projections for the next five years can be seen in Table 3.6 and 3.7 below.

\begin{tabular}{|c|c|c|c|c|c|c|}
\hline Item & Unit & Y.1 & Y.2 & Y.3 & Y.4 & Y.5 \\
\hline
\end{tabular}

Table 3.6 PT OAM Human Capital Cost

\begin{tabular}{|l|c|c|c|c|c|c|}
\hline Ttem & Unit & Y.1 & Y.2 & Y.3 & Y.4 & Y.5 \\
\hline Human Capital Cost & IDR(Rp.000) & $1,095,773$ & $1,668,677$ & $1,967,069$ & $2,125,016$ & $2,284,898$ \\
\hline
\end{tabular}

\section{CONCLUSION}

As a newly established startup company, PT OAM needs to be thorough and detailed in preparing and implementing each of its human capital activities. This is because people are the most important aspect in the organization. Recruitment, training and development, as well as cultural adoption are very important at this stage. In addition, the determination of a clear organizational structure and a good industrial relations system must be built from the start, as a foundation for the company's human capital. 


\section{Acknowledgement: None}

\section{Conflict of Interest: None}

\section{Source of Funding: None}

\section{REFERENCES}

1. Acemoglu, D., \& Pischke, J. S. (1999). The structure of wages and investment in general training. Journal of political economy, 107(3), 539-572.

2. Armstong, M., \& Taylor, A. S. (2010). Human Resource Management Practice. In The SAGE Handbook of Human Resource Management. https://doi.org/10.4135/9780857021496.

3. Bruns, T., \& Stalker, G. M. (1961). The management of innovation. Tavistock, London, 120-122.

4. David, F. R. (2011). Strategic Management: Concepts and Cases. Thirteenth, Global Edition.

5. Drucker, P. F. (2006). Knowledge-worker productivity the biggest challenge. IEEE Engineering Management Review, 34(2), 29-39. https://doi.org/10.1109/emr.2006.1679053.

6. Edgar H. Schein. (2004). Organizational culture and leadership. The Jossey-Bass Business \& Management Series. https://doi.org/10.1016/j.sbspro.2011.12.156

7. Eriyanto, Y., Lestariani, R. I., Syah, T. Y. R., \& Indradewa, R. (2021). Human Capital Implementation Strategy in the Kamala Fertility Clinic. Journal of Multidisciplinary Academic, 05(01), 89-93.

8. Mintzberg, H. (1980). Structure in 5's: A Synthesis of the Research on Organization Design. Management Science, 26(3), 322341. https://doi.org/10.1287/mnsc.26.3.322.

9. Mohammed, J., Bhatti, M. K., Jariko, G. A., \& Zehri, A. W. (2013). Importance of Human Resource Investment for Organizations and Economy: A Critical Analysis. Journal of Managerial Sciences, 7(1), 127-133. Retrieved from http://search.ebscohost.com/login.aspx?dire $\mathrm{ct}=\mathrm{true} \& \mathrm{db}=\mathrm{bth} \& \mathrm{AN}=87064142 \&$ site $=$ ehos $\mathrm{t}$-live \&scope $=$ site.
10. Niam, J., \& Syah, T. Y. R. (2019). Pengaruh Motivasi, Kepemimpinan dan Budaya Organisasi Terhadap Kepuasan Kerja serta Dampaknya pada Kinerja Karyawan (Vol. 12 , p. 89). Vol. 12, p. 89. https://doi.org/10.31315/opsi.v12i2.3147.

11. Nugraha, E. M., \& Handayani, I. G. A. K. R. (2020). Kemenkas Nomor HK. 01.07 Menkes 3822020 Sebagai Pembuka Jalan Perekonomian Indonesia dalam masa New Normal. In Seminar Nasional \& Call for Papers 2020 (p. 39).

12. Peek, B., \& Chen, H. (2011). Promoting innovations in a lean organization through innovative value stream mapping. In 2011 Proceedings of PICMET'11: Technology Management in the Energy Smart World (PICMET) (pp. 1-9). IEEE.

13. Pernkopf-Konhäusner, K., \& Brandl, J. (2011). Variations in evaluative repertoires: Comparing employee perspectives on training and development in Germany and Russia. Personnel Review.

14. Putra, R. P., Yanuar, T., Syah, R., Pusaka, S., \& Indradewa, R. (2019). Human Resources Implementation Using the McKinsey 7S Method for Business Startup: Duck Nugget Frozen Food. Journal of Multidisciplinary Academic 11 JoMA, Vol. 03. Retrieved from https://kemalapublisher.com/index.php/JoM A/article/view/366.

15. Sidabutar, E., Syah, T. Y. R., \& Anindita, R. (2020). The impact of compensation, motivation, and job satisfaction on employee performance. Journal of Multidisciplinary Academic, 4(1), 1-5. International Business Management. https://doi.org/10.3923/ibm.2016.4907.4916

16. Townsend, K. (2007). Recruitment, training and turnover another call centre paradox, Personnel Review, Vol. 36 No. 3, pp. 476490.doi.org10.110800483480710731383.pd f.

How to cite this article: Saputra A, Indradewa R, Syah TYR et.al. Human capital plan for business startups "jamu partnership" in Indonesia. International Journal of Research and Review. 2021; 8(8): 370-376. DOI: https://doi.org/10.52403/ijrr.20210851 